\title{
PENGARUH KINERJA KEUANGAN PEMERINTAH DAERAH TERHADAP BELANJA MODAL UNTUK PELAYANAN PUBLIK (Studi pada kabupaten dan kota di Provinsi Sulawesi Utara)
}

\author{
Julius Tamawiwy \\ Jullie J Sondakh \\ Jessy D.L Warongan
}

(Email: julius.tamawiwy@yahoo.com)

\begin{abstract}
The main objective of regional autonomy is to improve public services and promote the local economy in Indonesia. Capital expenditures for public services is used to finance expenditure in investing activities (add assets) aimed at improving public infrastructure that results can be used directly by the public. Developed regions tend to maintain the structure of expenditure into maintenance expenditure. The shift in spending patterns in the local government often triggered concerns about the extent to which the amount of local revenue affects the pattern of local government spending, especially capital expenditure for public services.

This study purposes to analyze growth of revenue (PAD), the fiscal decentralization, financial effectiveness and efficiency of the Local Government Financial Management to the capital expenditure for public services. The method used is quantitative method with a sampling technique using judgment sampling which took samples with consideration of the availability of data in the Local Government Financial Statements Reports in the Province of North Sulawesi by 10 districts/cities of Local Government in North Sulawesi since 2010 to 2015. The analytical method used is a multiple regression using SPSS 20 application assistance.

The results show that PAD growth is effect as positive and significant capital expenditures for public services, fiscal decentralization is negative effect and not significant toward capital expenditures for public services, effectiveness and efficiency of local financial is effect as positive but not significant toward capital expenditures for public services..
\end{abstract}

\section{PENDAHULUAN}

\subsection{Latar Belakang Masalah}

Pada organisasi bisnis terdapat dua pihak yang memiliki kepentingan utama atas organisasi tersebut, yaitu pemilik dan manajemen. Pemilik sebagai prinsipal memberikan mandate kepada manajemen sebagai agen untuk menjalankan organisasi demi kepentingan prinsipal. Namun demikian dalam hubungan prinsipal-agen (principal-agent) ini sering terjadi perbedaan kepentingan (conflict of interest) antara prinsipal dan agen yang disebut sebagai masalah keagenan (agency problem). Dengan kata lain, agen bertindak tidak sejalan dengan kepentingan prinsipal dan hal ini akan berpengaruh kepada kinerja organisasi.

Menurut Zimmerman (1977), agency problem juga terjadi pada organisasi pemerintahan, rakyat sebagai prinsipal memberikan mandat kepada pemerintah sebagai agen, untuk menjalankan tugas pemerintahan dalam rangka meningkatkan kesejahteraan rakyat. Lane (2003) dikutip Halim dan Abdullah (2003) juga menjelaskan bahwa teori keagenan bisa diterapkan dalam organisasi sektor publik dan menyatakan bahwa negara demokrasi modern didasarkan pada hubungan prinsipal-agen. Hal ini didukung oleh pernyataan Moe (1984) yang menjelaskan konsep ekonomika organisasi sektor publik dengan menggunakan teori keagenan.

Dalam konteks pemerintahan, moral hazard pemerintah daerah dipertanyakan dalam hal ini tentang kelanjutan penggunaan penerimaan daerah khususnya Pendapatan Asli Daerah (PAD). PAD yang tinggi mencerminkan keuangan daerah yang maju, sehingga pengalokasian 
untuk belanja modal perlu menjadi perhatian. Daerah yang maju cenderung mempertahankan struktur belanja menjadi belanja pemeliharaan, tidak serta-merta untuk belanja modal saja (Handayani, 2011). Pergeseran pola belanja ini yang menjadi permasalahan krusial di pemerintah daerah mengingat sejauh mana pentingnya diadakan pendanaan untuk belanja modal. Menurut Abdul Halim (2011:220), sudah sewajarnya anggaran belanja daerah dialokasikan pada kepentingan publik.

Kinerja keuangan dapat digunakan sebagai ukuran keberhasilan daerah otonom dalam menyelenggarakan otonomi daerah. Dengan melihat kinerja keuangan dapat mengetahui akuntabilitas dari para pemangku kekuasaan, dimana setiap rupiah uang publik harus dipertanggungjawabkan kepada masyarakat yang telah memberikan uangnya untuk membiayai pembangunan dan roda pemerintahan (Mahmudi, 2006).

Motivasi yang melandasi penelitian ini antara lain adanya pergeseran pola belanja dalam pemerintah daerah khususnya belanja modal untuk pelayanan publik. Hal ini memicu permasalahan tentang sejauh mana besarnya pendapatan daerah mempengaruhi pola belanja pemerintah daerah khususnya belanja modal untuk pelayanan publik. Beberapa studi empiris yang telah dilakukan menunjukkan bahwa upaya pemerintah daerah untuk meningkatkan panerimaan daerah telah menimbulkan distorsi pasar dan high cost economy (Saad, Ilyas., 2003). Selain itu, upaya-upaya yang dilakukan pemerintah daerah untuk meningkatkan penerimaan daerah kurang diikuti upaya untuk meningkatkan perlayanan publik (Halim, 2004).

Belanja modal jenis pelayanan publik adalah belanja yang digunakan untuk membiayai kegiatan investasi (menambah aset) yang ditujukan untuk peningkatan sarana dan prasarana publik yang hasilnya dapat digunakan langsung oleh masyarakat. Belanja modal yang dialokasikan oleh pemerintah dapat dipengaruhi oleh berbagai faktor yang terkait dengan kinerja keuangan daerah diantaranya: (1) PAD; (2) desentralisasi fiskal; (3) efektivitas keuangan daerah, dan (4) efisiensi keuangan daerah. Pertama, pada kondisi infrastruktur daerah yang masih terbatas, maka secara logis pertumbuhan PAD seharusnya lebih banyak diarahkan untuk belanja modal ketimbang belanja lainnya. Pada tahun 2014, rerata pertumbuhan PAD untuk 10 Kabupaten/Kota di Sulawesi Utara sebesar 2,897\% dan mengalami percepatan pertumbuhan pada tahun 2015 yaitu menjadi rerata 5,389\%.

Beberapa penelitian menemukan bahwa pertumbuhan PAD memiliki pengaruh positif dan signifikan terhadap belanja modal (Ardhini, 2011; Fitri, 2013; Verawati, 2015; Sularso dan Restianto, 2011; Nopiani, Cipta, dan Yudiatmaja, 2016). Sebaliknya Yovita (2011) menemukan hasil yang sebaliknya dimana PAD tidak berpengaruh signifikan terhadap belanja modal.

Kedua, desentralisasi fiskal daerah merupakan prasyarat penting dalam pelaksanaan otonomi daerah. Suatu daerah dikatakan mampu untuk melaksanakan otonomi daerah salah satu cirinya terletak pada kemampuan keuangan daerah. Artinya, daerah otonom harus memiliki kewenangan dan kemampuan untuk menggali sumber-sumber keuangan sendiri, mengelola dan menggunakan keuangan sendiri yang cukup memadai untuk membiayai penyelenggaraan pemerintah daerah dan penyediaan barang publik.

Rasio desentralisasi fiskal, diukur dengan cara membandingkan jumlah pendapatan asli daerah dan total penerimaan daerah. Penelitian yang dilakukan Assyurriani (2015) menunjukkan bahwa desentralisasi fiskal pemerintah daerah berpengaruh terhadap belanja modal. Pada tahun 2014, besarnya rasio desentralisasi fiskal rata-rata untuk 10 Kabupaten/Kota di Sulawesi Utara rerata 3,959\% sementara pada tahun 2015 meningkat menjadi 5,441\%.

Beberapa penelitian menemukan pengaruh positif dan signifikan dari rasio desentralisasi fiskal terhadap belanja modal (Ardhini dan Handayani, 2011; Hidayat, 2013). Di sisi lain, Assyurriani (2015) dan Badrudin (2012) menemukan bahwa rasio densentralisasi fiskal tidak berpengaruh terhadap belanja modal.

Ketiga, kemampuan pemerintah daerah untuk melakukan belanja modal tergantung juga pada kemampuan suatu daerah untuk mencapai target pendapatan atau efektivitas. Apabila target pendapatan tercapai maka pemerintah daerah dapat melakukan belanja modal sesuai yang 
dianggarkan tanpa pemotongan, bahkan dapat ditingkatkan jika realisasi pendapatan di atas target.

Rasio efektivitas diukur dengan cara membandingkan jumlah realisasi PAD dan target PAD yang dihitung berdasarkan alokasi PAD tahun bersangkutan, sehingga suatu daerah dapat dikatakan efektif apabila jumlah realisasi pendapatan lebih tinggi daripada target yang ditetapkan. Rata-rata rasio efektivitas keuangan pada 10 Kabupaten/Kota di Sulawesi Utara untuk tahun 2014 sebesar 130,08\% dan meningkat menjadi rerata 153,55\% pada tahun 2015 . Hasil ini mengindikasikan dua hal, yaitu peningkatan kinerja pengumpulan PAD pemerintah atau penetapan target pendapatan yang terlalu rendah.

Penelitian Ardhini dan Handayani (2011) serta Hidayat (2013) menemukan bahwa rasio efektivitas berpengaruh positif dan signifikan terhadap pengalokasian belanja modal. Sebaliknya penelitian yang dilakukan Assyurriani (2015) menemukan bahwa rasio efektivitas keuangan daerah tidak berpengaruh terhadap belanja modal.

Keempat, pemerintah yang dapat mencapai efisiensi keuangan maka akan tersedia dana lebih untuk meningkatkan belanja modal. Rasio efisiensi keuangan daerah, diukur dengan cara membandingkan total pengeluaran daerah dengan total pendapatan daerah. Suatu daerah dikatakan efisien jika pengeluaran daerah kecil dan total pendapatannya tinggi. Rerata rasio efisiensi untuk 10 Kabupaten/Kota di Sulawesi Utara pada tahun 2014 sebesar 91,79\% sementara pada tahun 2015 sebesar 97,97\%. Kondisi ini mengindikasikan terjadi penurunan efisiensi pemerintah kabupaten/kota tersebut.

Penelitian yang telah dilakukan oleh Fitri (2013), Hidayat (2013), Ardhini dan Handayani (2011), Vegasari (2011), serta Verawaty (2015) menemukan bahwa efisiensi keuangan berpengaruh signifikan terhadap belanja modal. Berbeda dengan temuan Assyurriani (2015) dimana efisiensi keuangan daerah tidak berpengaruh terhadap belanja modal. Penelitian tesis ini difokuskan untuk menganalisia pengaruh kinerja keuangan pemerintah daerah terhadap alokasi belanja modal untuk pelayanan publik.

\subsection{Rumusan Masalah}

Berdasarkan uraian latar belakang diatas, maka rumusan masalah dalam penelitian ini adalah Apakah Pertumbuhan PAD, Desentralisasi Fiskal, Efektivitas Keuangan Daerah, Efisiensi Keuangan Daerah berpengaruh signifikan terhadap Belanja Modal untuk pelayanan publik Pemerintah Kabupaten dan Kota di Provinsi Sulawesi Utara baik secara parsial maupun simultan?

\subsection{Landasan Teori}

\section{TINJAUAN PUSTAKA}

\section{Teori Keagenan}

Jensen dan Meckling (1976) menyatakan bahwa hubungan keagenan adalah sebuah kontrak antara manajemen (agent) dengan pemegang saham (principal). Hubugan kegenan tersebut terkadang menimbulkan masalah antara manajemen dan pemegang saham. Konflik yang terjadi karena manusia adalah makhluk ekonomi yang mempunyai sifat dasar mementingkan kepentingan diri sendiri. Pemegang saham dan manajemen memiliki tujuan yang berbeda dan masing masing menginginkan tujuan mereka terpenuhi. Akibat yang terjadi adalah munculnya konflik kepentingan. Pemegang saham menginginkan pengembalian yang lebih besar dan secepat-cepatnya atas investasi yang mereka tanamkan sedangkan manajemen menginginkan kepentingannya diakomodasi dengan pemberian kompensasi atau insentif yang sebesar-besarnya atas kinerjanya dalam menjalankan perusahaan. Karena unit analisis dalam teori keagenan adalah kontrak yang melandasi hubungan antara prinsipal dan agen, maka fokus dari teori ini adalah pada penentuan kontrak yang paling efisien yang mendasari hubungan antara prinsipal dan agen.

Jensen dan Meckling (1976) menjelaskan hubungan antara prinsipal, dalam hal ini pemegang saham, dan agen-agen sebagai manajemen. Dalam hubungan ini, pemegang saham menyerahkan wewenang mereka kepada manajemen untuk mengelola asset-aset perusahaan agar 
bisa memberikan keuntungan untuk mereka. Adanya pendelegasian wewenang ini bisa menimbulkan permasalahan. 


\section{Pelayanan Publik}

Pelayanan adalah suatu bentuk kegiatan pelayanan yang dilaksanakan oleh instansi pemerintah baik di pusat, di daerah, BUMN, dan BUMD dalam bentuk barang maupun jasa dalam rangka pemenuhan kebutuhan masyarakat sesuai peraturan perundang-undangan yang berlaku (KEPMENPAN No. 81 tahun 1993).

Pelayanan publik dapat diartikan sebagai pemberian layanan (melayani) keperluan orang atau masyarakat yang mempunyai kepentingan pada organisasi itu sesuai dengan aturan pokok dan tata cara yang telah ditetapkan.

Menurut Keputusan MENPAN Nomor 63 tahun 2003, mengenai pelayanan adalah sebagai berikut.

1. Pelayanan Publik adalah segala kegiatan pelayanan yang dilaksanakan oleh penyelenggara pelayanan publik sebagai upaya pemenuhan kebutuhan penerima pelayanan maupun pelaksanaan ketentuan Peraturan Perundang-undangan.

2. Penyelenggaraan adalah pelayanan Publik adalah Instansi Pemerintah.

3. Instansi Pemerintah adalah sebutan kolektif meliputi satuan kerja satuan organisasi Kementrian, Departemen, Kesekretariatan Lembaga Tertinggi dan Tinggi Negara, dan instansi Pemerintah lainnya, baik pusat maupun Daerah termasuk Badan Usaha Milik Daerah.

4. Unit penyelenggara pelayanan publik adalah unit kerja pada instansi Pemerintah yang secara langsung memberikan pelayanan kepada penerima pelayanan publik.

5. Pemberi pelayanan publik adalah pejabat/ pegawai instansi pemerintah yang melaksanakan tugas dan fungsi pelayanan publik sesuai dengan peraturan perundangundangan.

6. Penerima pelayanan publik adalah orang, masyarakat, instansi pemerintah dan badan hukum yang menerima pelayanan dari instansi pemerintah.

\section{Kinerja Keuangan Daerah}

Kinerja merupakan pencapaian atas apa yang direncanakan, baik oleh pribadi maupun organisasi. Apabila pencapaian sesuai dengan yang direncanakan, maka kinerja yang dilakukan terlaksana dengan baik. Kinerja Keuangan adalah suatu ukuran kinerja yang menggunakan indikator keuangan. Analisis kinerja keuangan pada dasarnya dilakukan untuk menilai kinerja dimasa lalu dengan melakukan berbagai analisis sehingga diperoleh posisi keuangan yang mewakili realitas entitas dan potensi-potensi kinerja yang akan berlanjut.

Dalam penelitian ini, istilah yang penulis maksudkan dengan Kinerja Keuangan Pemerintah Daerah adalah tingkat pencapaian dari suatu hasil kerja di bidang keuangan daerah yang meliputi penerimaan dan belanja daerah dengan menggunakan indikator keuangan yang ditetapkan melalui suatu kebijakan atau ketentuan perundang-undangan selama satu periode anggaran. Bentuk kinerja tersebut berupa rasio keuangan yang terbentuk dari unsur Laporan Pertangggungjawaban Kepala Daerah berupa Perhitungan APBD.

\section{Analisis Kinerja Keuangan Daerah}

Analisis kinerja keuangan diukur melalui penghitungan rasio-rasio keuangan yang merupakan alat ukur kinerja keuangan. Rumus yang digunakan dalam mengukur kinerja keuangan Pemerintah Kabupaten/Kota/Provinsi menurut Halim (2012:127) antara lain sebagai berikut.

1. Rasio Pertumbuhan PAD

Rasio pertumbuhan (Growth Ratio) mengukur seberapa besar kemampuan pemerintah daerah dalam mempertahankan dan meningkatkan keberhasilannya yang telah dicapai dari periode ke periode berikutnya. dengan formulasi sebagai berikut. 
Rasio Pertumbuhan PAD = 
Kriteria untuk menetapkan ketergantungan keuangan daerah dapat dilihat Tabel.

\begin{tabular}{|c|c|}
\hline Prosentase Pertumbuhan PAD & Kriteria \\
\hline $0,00-10.00$ & Sangat Rendah \\
$10,01-20,00$ & Rendah \\
$20,01-30,00$ & Sedang \\
$30,01-40,00$ & Cukup \\
$40,01-50,00$ & Tinggi \\
$>50,00$ & Sangat Tinggi \\
\hline
\end{tabular}

Sumber : Tim Litbang Depdagri (1991)

2. Rasio Desentralisasi Fiskal

Tingkat Desentralisasi Fiskal adalah ukuran untuk menunjukkan tingkat kewenangan dan tanggung jawab yang diberikan pemerintah pusat kepada pemerintah daerah untuk melaksanakan pembangunan. Tingkat desentralisasi fiskal dalam penelitian ini diukur dengan menggunakan rasio PAD terhadap total penerimaan daerah. Berikut formula untuk mengukur tingkat Desentralisasi Fiskal.

\section{Rasio Desentralisasi Fiskal =}

Selanjutnya, kriteria untuk menetapkan ketergantungan keuangan daerah dapat dikatagorikan seperti Tabel.

\begin{tabular}{|c|c|}
\hline Prosentase PAD terhadap TPD & $\begin{array}{c}\text { Tingkat Desentralisasi } \\
\text { Fiskal }\end{array}$ \\
\hline $0,00-10.00$ & Sangat Kurang \\
$10,01-20,00$ & Kurang \\
$20,01-30,00$ & Sedang \\
$30,01-40,00$ & Cukup \\
$40,01-50,00$ & Baik \\
$>50,00$ & Sangat Baik \\
\hline
\end{tabular}

Sumber : Tim Litbang Depdagri (1991)

\section{Rasio Efektivitas}

Pengukuran tingkat efektivitas ini untuk mengetahui berhasil tidaknya pencapaian tujuan anggaran yang memerlukan data-data realisasi pendapatan dan target pendapatan. Analisis efektivitas menggambarkan kemampuan pemda dalam merealisasikan PAD yang direncanakan dibandingkan dengan target PAD yang ditetapkan Berikut formula untuk mengukur tingkat Efektivitas.

\section{Rasio Efektivitas =}

Kriteria untuk menetapkan Efektivitas pengelolaan keuangan daerah dapat dilihat pada Tabel.

\begin{tabular}{|c|c|}
\hline Prosentase Kinerja Keuangan & Kriteria \\
\hline Diatas $100 \%$ & Sangat Efektif \\
$90 \%-100 \%$ & Efektif \\
$80 \%-90 \%$ & Cukup Efektif \\
$60 \%-80 \%$ & Kurang Efektif \\
Kurang dari $60 \%$ & Tidak Efektif \\
\hline
\end{tabular}

Sumber : Kepmendagri No. 690.900.327 Tahun 1996 


\section{Rasio Efisiensi}

Pengukuran tingkat efisiensi ini untuk mengetahui seberapa besar efisiensi dari pelaksanaan suatu kegiatan dengan mengukur input digunakan dan membandingkan dengan output yang dihasilkan yang memerlukan data-data realisasi belanja dan realisasi pendapatan.

Rasio efisiensi adalah rasio yang menggambarkan perbandingan antara output dan input atau realisasi pengeluaran dengan realisasi penerimaan daerah. Semakin kecil rasio ini, maka semakin efisien, begitu pula sebaliknya. Suatu kegiatan dikatakan telah dikerjakan secara efisien jika pelaksanaan pekerjaan tersebut telah mencapai hasil (output) dengan biaya (input) yang terendah atau dengan biaya minimal diperoleh hasil yang diinginkan. Berikut formula untuk mengukur tingkat Efisiensi sebagai berikut.

$$
\text { Rasio Efisiensi = }
$$

Kriteria untuk menetapkan Efisiensi pengelolaan keuangan daerah dapat dilihat pada Tabel.

\begin{tabular}{|c|c|}
\hline Prosentase Kinerja Keuangan & Kriteria \\
\hline Di atas $100 \%$ & Tidak Efisien \\
$90 \%-100 \%$ & Kurang Efisien \\
$80 \%-90 \%$ & Cukup Efektif \\
$60 \%-80 \%$ & Efisien \\
Kurang dari $60 \%$ & Sangat Efisien \\
\hline
\end{tabular}

Sumber : Kepmendagri No. 690.900.327 Tahun 1996

\section{Belanja Modal (Capital Expenditure)}

Capital expenditure atau belanja modal merupakan pengeluaran dalam memperoleh asset tetap yang manfaatnya dapat dinikmati lebih dari satu periode akuntansi. Capital expenditure perlu untuk dilakukan oleh perusahaan di dalam menjalankan kegiatan operasionalnya. Capital expenditure merupakan sejumlah pengeluaran dana yang dilakukan oleh manajemen terhadap property, plan, equipment, (Griner dan Gordon, 1995). Capital expenditure disebut dengan istilah pembelanjaan perusahaan dan didefenisikan sebagai pengalokasian dana untuk diinvestasikan dalam berbagai asset perusahaan (Riyanto, 2001).

Definisi capital expenditure sebagai suatu pengeluaran dana oleh perusahaan yang diharapkan akan menghasilkan manfaat selama periode waktu lebih dari satu tahun. Defini ini menyoroti faktor kunci, manfaat dan jangka waktu lebih dari satu tahun (Gitman, 2003). capital expenditure merupakan investasi yang dikeluarkan dengan harapan menghasilkan aliran kas masuk di masa depan.

\section{Belanja Modal untuk Pelayanan Publik}

Belanja Modal termasuk jenis Belanja Langsung dan digunakan untuk pengeluaran yang dilakukan dalam rangka pembelian/pengadaan atau pembangunan aset tetap berwujud yang mempunyai nilai manfaat lebih dari 12 (duabelas) bulan untuk digunakan dalam kegiatan pemerintahan, seperti dalam bentuk tanah, peralatan dan mesin, gedung dan bangunan, jalan, irigasi dan jaringan, dan aset tetap lainnya ( Permendagri No. 21 tahun 2011).

Peningkatan Pemerintah Daerah dalam investasi modal (belanja modal) diharapkan mampu meningkatkan kualitas layanan publik dan pada gilirannya mampu meningkatkan tingkat partisipasi (kontribusi) publik terhadap pembangunan. Hal ini berarti dengan bertambahnya belanja modal maka akan berdampak pada periode yang akan datang yaitu produktivitas masyarakat meningkat dan bertambahnya investor. Belanja modal merupakan pengeluaran pemerintah daerah yang manfaatnya melebihi satu tahun anggaran dan akan menambah aset atau kekayaan daerah dan selanjutnya akan menambah belanja yang bersifat rutin seperti biaya operasi dan pemeliharaan. 
Belanja modal jenis Pelayanan Publik adalah belanja yang digunakan untuk membiayai kegiatan investasi (menambah aset) yang ditujukan untuk peningkatan sarana dan prasarana publik yang hasilnya dapat digunakan langsung oleh masyarakat. Belanja modal jenis ini terdiri atas belanja tanah, belanja modal jalan dan jembatan, belanja modal bangunan air (irigasi), belanja modal instalasi, belanja modal jaringan, belanja modal bangunan gedung untuk kegiatan kemasyarakatan, belanja modal monumen, belanja modal alat-alat angkutan, alat-alat bengkel, alat-alat alat-alat kedokteran, alat-alat laboratorium, belanja modal buku/perpustakaan, barang bercorak kesenian dan budaya, belanja modal hewan ternak serta tanaman, belanja modal alatalat persenjataan/keamanan. Belanja modal untuk pelayanan publik disusun atas dasar kebutuhan nyata masyarakat sesuai dengan tuntutan dan dinamika yang berkembang untuk meningkatkan pelayanan dan kesejahteraan masyarakat yang lebih baik.

\subsection{Penelitian Terdahulu}

Stine (1994) melakukan penelitian dengan judul penelitian yaitu "Is Local Government Response to Federal Aid Symmetrical?". Stine menguji hipotesis mengenai respon fiskal asimetris bantuan antar pemerintah. Pengujian yang dilakukan terhadap 66 Pemerintah Kota di Pennsylvania dari tahun 1978-1988 membuktikan bahwa penerimaan pemerintah hendaknya lebih banyak untuk program-program layanan publik.

Lago-Peñas (2005) dengan menggunakan data dari pemerintah kota Galician menunjukkan bahwa reaksi terhadap kenaikan atau penurunan dana transfer/dana bantuan adalah tidak simetris. Dijelaskan bahwa marginal propensity untuk belanja ketika dana transfer naik adalah 0.9, sementara marginal propensity untuk mengurangi belanja ketika dana transfer berkurang adalah 0.7 .

Lin dan Liu (2006) meneliti tentang "Fiscal Decntralization and Economic Growth in China". Hasil penelitian mengungkapkan bahwa belanja pembangunan merupakan upaya logis yang dilakukan pemerintah daerah dalam meningkatkan kepercayaan publik dalam rangka meningkatkan pertumbuhan ekonomi daerah. Penelitian tersebut menemukan adanya hubungan yang kuat antara belanja pembangunan dengan tingkat desentralisasi yang mana akan mendorong dan mempercepat pertumbuhan ekonomi di daerah.

Nguyen dan Anwar (2011), meneliti tentang "Fiscal Decentralization and Economic Growth in Vietnam". Menyimpulkan bahwa desentralisasi fiskal berpengaruh positif dari sisi pendapatan, tetapi negatif dari sisi pengeluaran.

Halim (2004) yang meneliti tentang teori keagenan di dalam penganggaran sektor publik berpendapat bahwa hubungan dan masalah keagenan dalam penganggaran antara eksekutif dan legislatif merupakan bagian tak terpisahkan dalam penelitian keuangan (termasuk akuntansi) publik, politik penganggaran, dan ekonomika publik. Eksekutif merupakan agen bagi legislatif dan publik (dual accountability) dan legislatif agen bagi publik. Konsep perwakilan (representativeness) dalam penganggaran tidak sepenuhnya berjalan ketika kepentingan publik tidak terbela seluruhnya oleh karena adanya perilaku oportunistik (moral hazard) legislatif. Di sisi lain, eksekutif sebagai agen cenderung menjadi budget maximizer karena berperilaku oportunistik (adverse selecation dan moral hazard sekaligus).

Ardhini dan Handayani (2011) meneliti tentang pengaruh rasio keuangan daerah terhadap belanja modal untuk pelayanan publik. Hasil penelitian menunjukkan bahwa rasio kemandirian berpengaruh terhadap belanja modal untuk pelayanan publik, tingkat efektivitas berpengaruh positif signifikan terhadap belanja modal, efisiensi berpengaruh negatif namun signifikan terhadap belanja modal untuk pelayanan publik.

Sularso dan Restianto (2011) meneliti Pengaruh Kinerja Keuangan Terhadap Alokasi belanja Modal dan Pertumbuhan Ekonomi Kabupaten/Kota di Jawa Tengah. Hasil penelitian menunjukkan bahwa rasio ketergantungan keuangan, rasio kemandirian keuangan, rasio efektivitas PAD berpengaruh terhadap alokasi belanja modal serta rasio desentralisasi berpengaruh terhadap alokasi belanja modal. 
Hidayat (2013) meneliti Analisis Pengaruh Kinerja Keuangan Daerah Terhadap Alokasi Belanja Modal (Studi pada Kabupaten dan Kota di Jawa Timur). Hasil penelitian menunjukkan bahwa rasio kemandirian, rasio desentralisasi fiskal, rasio efektefitas, efisiensi dan tingkat pembiayaan SILPA berpengaruh signifikan terhadap alokasi belanja modal.

Martini dan Dwirandra (2015) meneliti tentang pengaruh kinerja keuangan daerah pada alokasi belanja modal di Provinsi Bali. Hasil penelitian menunjukkan bahwa rasio kemandirian dan rasio efisiensi serta tingkat pembiayaan SILPA berpengaruh negatif dan signifikan terhadap alokasi belannja modal, rasio desentralisasi fiskal berpengaruh positif dan signifikan terhadap alokasi belanja modal dan rasio BUMD berpengarruh positif namun tidak signifikan terhadap belanja alokasi belanja modal.

Assyurriani (2015) meneliti tentang pengaruh rasio kemandirian daerah, rasio efektivitas, rasio efesiensi, rasio aktivitas dan rasio pertumbuhan terhadap belanja modal pada pemerintah kabupaten dan pemerintah kota di kepulauan Riau tahun 2010-2013. Hasil penelitian menunjukkan bahwa rasio kemandirian, rasio efektivitas dan efisiensi tidak berpengaruh terhadap belanja modal, rasio pertumbuhan dan rasio aktifitas berpengaruh terhadap belanja modal.

\section{KERANGKA KONSEPTUAL}

\subsection{Kerangka Pemikiran}

Penelitian ini untuk melihat pengaruh Kinerja Keuangan Pemerintah daerah yang terdiri dari Pertumbuhan PAD (X1), Desentralisasi Fiskal (X2), Efektivitas Keuangan Daerah (X3), Efisiensi Keuangan Daerah (X4) sebagai Variabel Independen dan Belanja Modal untuk pelayanan publik sebagai variabel dependen. Berdasarkan tinjauan penelitian terdahulu dan kajian teoritis serta permasalahan yang telah dikemukakan maka secara sistematik kerangka pemikiran dapat digambarkan sebagai berikut.

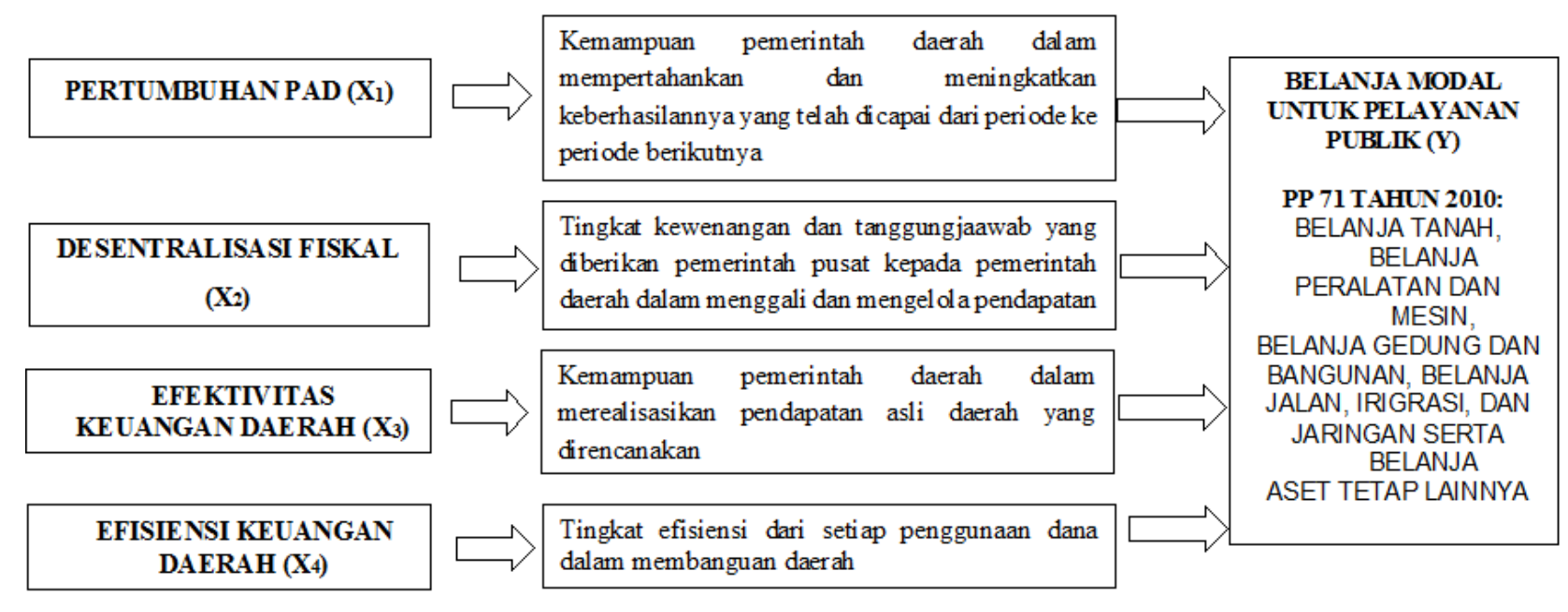

Gambar Kerangka Konseptual Penelitian

\subsection{Hipotesis Penelitian}

$\mathrm{H}_{1}$ : Pertumbuhan PAD berpengaruh terhadap belanja modal untuk pelayanan publik Pemerintah Kabupaten dan Kota di Provinsi Sulawesi Utara.

$\mathrm{H}_{2}$ : Desentralisasi fiskal berpengaruh terhadap belanja modal untuk pelayanan publik Pemerintah Kabupaten dan Kota di Provinsi Sulawesi Utara. 
$\mathrm{H}_{3}$ : Efektivitas keuangan daerah berpengaruh terhadap belanja modal untuk pelayanan publik Pemerintah Kabupaten dan Kota di Provinsi Sulawesi Utara.

$\mathrm{H}_{4}$ : Efisiensi keuangan daerah berpengaruh terhadap belanja modal untuk pelayanan publik Pemerintah Kabupaten dan Kota di Provinsi Sulawesi Utara.

\section{METODE PENELITIAN}

\section{Jenis/Rancangan Penelitian}

Penelitian ini merupakan jenis penelitian kuantitatif. Menurut Sugiyono (2012), metode penelitian kuantitatif dapat diartikan sebagai metode penelitian yang berlandaskan pada filsafat positivisme, digunakan untuk meneliti pada populasi atau sampel tertentu. analisis data bersifat kuantitatif/statistik dengan tujuan untuk menguji hipotesis yang telah ditetapkan (Sugiyono, 2012: 7).

\section{Populasi dan Sampel}

Penelitian ini mengambil 10 kabupaten dan kota berdasarkan pertimbangan (judgment Sampling) tersedianya data yang menyampaikan Laporan Realisasi APBD Tahun 2010 hingga 2015 dengan lengkap di situs Dirjen Perimbangan Keuangan.

\section{Jenis dan Sumber Data}

Data yang dianalisis dalam penelitian ini adalah data sekunder yaitu data yang telah diolah lebih lanjut dan disajikan oleh pihak lain. Penelitian ini menggunakan pooled data, selama periode tahun 2010 sampai dengan 2015. Data penelitian antara lain berupa Data Realisasi PAD, Total Penerimaan Daerah,DAU,dan Belanja Modal dari Laporan Realisasi APBD Pemerintah Kabupaten dan Kota di Provinsi Sulawesi Utara tahun 2010-2015.

\section{Variabel Penelitian dan Definisi Operasional Variabel}

Definisi operasional dimaksudkan untuk menjabarkan variabel ke dalam suatu penelitian yang berupa indikator yang lebih terperinci, sehingga akan mempermudah pengukurannya. Pengukuran secara operasional adalah :

1. Belanja Modal untuk pelayanan Publik adalah pengeluaran yang dilakukan dalam rangka pembelian/pengadaan atau pembangunan aset tetap berwujud yang mempunyai nilai manfaat lebih dari 12 (duabelas) bulan untuk digunakan dalam kegiatan pemerintahan, dengan formula:

$$
\text { Belanja Modal = }
$$

2. Rasio Pertumbuhan PAD adalah mengukur seberapa besar kemampuan pemerintah daerah dalam mempertahankan dan meningkatkan keberhasilannya yang telah dicapai dari periode ke periode berikutnya. Yang diukur dengan realisasi penerimaan PAD tahun berjalan dikurangi tahun sebelumnya dibagi dengan realisasi penerimaan PAD tahun sebelumnya. dengan Formulasi sebagai berikut :

$$
\text { Rasio Pertumbuhan = }
$$

3. Rasio Desentralisasi Fiskal adalah ukuran untuk menunjukkan tingkat kewenangan dan tanggung jawab yang diberikan pemerintah pusat kepada pemerintah daerah untuk melaksanakan pembangunan. Tingkat desentralisasi fiskal dalam penelitian ini diukur dengan menggunakan rasio PAD terhadap total penerimaan daerah. Berikut formula untuk mengukur tingkat Desentralisasi Fiskal :

$$
\text { Rasio Desentralisasi Fiskal = }
$$


4. Rasio Efektivitas Keuangan adalah gambaran kemampuan pemda dalam merealisasikan PAD yang direncanakan dibandingkan dengan target PAD yang ditetapkan. Berikut formula untuk mengukur tingkat Efektivitas:

Rasio Efektivitas =

5. Rasio Efisiensi Keuangan adalah ukuran yang menunjukkan tingkat efisiensi dari setiap penggunaan uang dalam membangun daerahnya. Berikut formula untuk mengukur tingkat Efisiensi:

Rasio Efisiensi =

Tabel Definisi Operasional Variabel

\begin{tabular}{|c|l|l|c|}
\hline No. & \multicolumn{1}{|c|}{ Variabel } & \multicolumn{1}{|c|}{ Definisi Operasional } & $\begin{array}{c}\text { Skala } \\
\text { Pengukuran }\end{array}$ \\
\hline 1. & $\begin{array}{l}\text { Belanja Modal } \\
\text { untuk Pelayanan } \\
\text { Publik }(Y)\end{array}$ & $\begin{array}{l}\text { Rasio yang menggambarkan perbandingaan } \\
\text { antara total belanja modal dengan total belanja }\end{array}$ & Rasio \\
\hline 2. & $\begin{array}{l}\text { Rasio Pertumbuhan } \\
\text { PAD (Growth) }\left(\mathrm{X}_{1}\right)\end{array}$ & $\begin{array}{l}\text { Rasio yang menggambarkan perbandingan } \\
\text { antara PAD tahun berjalan dikurangi PAD } \\
\text { tahun sebelumnya dan dibandingkan dengan } \\
\text { PAD tahun sebelumnya }\end{array}$ & Rasio \\
\hline 3 & $\begin{array}{l}\text { Rasio Desentralisasi } \\
\text { Fiskal }(\mathrm{DF})\left(\mathrm{X}_{2}\right)\end{array}$ & $\begin{array}{l}\text { Rasio yang menggambarkan perbandingan } \\
\text { antara PAD dengan total penerimaan daerah }\end{array}$ & Rasio \\
\hline 4. & $\begin{array}{l}\text { Rasio Efektivitas } \\
\text { Keuangan Daerah - } \\
\text { EFEKD }\left(\mathrm{X}_{3}\right)\end{array}$ & $\begin{array}{l}\text { Rasio yang menggarkan perbandingan antara } \\
\text { realisasi pendapatan asli daerah dengan target } \\
\text { penerimaan daerah }\end{array}$ & Rasio \\
\hline 5. & $\begin{array}{l}\text { Rasio Efisiensi } \\
\text { Keuangan Daerah - } \\
\text { EFIKD }\left(\mathrm{X}_{4}\right)\end{array}$ & $\begin{array}{l}\text { Rasio yang menggambarkan perbandingan } \\
\text { antara realisasi pengeluaran dengan realisasi } \\
\text { penerimaan }\end{array}$ & Rasio \\
\hline
\end{tabular}

Sumber : Diolah dari berbagai sumber 2016

\section{Metode Pengumpulan Data}

Metode pengambilan data sekunder, data dikumpulkan dengan metode dokumentasi. Ini dilakukan dengan mengumpulkan, mencatat dan menghitung data-data yang berhubungan dengan penelitian yang diperoleh dari situs resmi Direktorat Jenderal Perimbangan Keuangan (DJPK).

\section{Metode Analisis}

Penelitian ini dengan menggunakan pendekatan kuantitatif.,Alat analisis yang digunakan dalam penelitian ini adalah analisis regresi linier berganda. Teknik yang digunakan untuk mencari nilai persamaan regresi yaitu dengan analisis Least Squares (kuadrat terkecil) dengan meminimalkan jumlah dari kuadrat kesalahan. Dalam analisis regresi selain mengukur seberapa besar hubungan antara variabel independen dengan variabel dependen, juga menunjukkan bagaimana hubungan antara variabel independen dengan dependen, sehingga dapat membedakan variabel independen dengan variabel dependen tersebut (Ghozali, 2013).

\section{Pengujian Asumsi Klasik}

Pengujian regresi linier berganda dapat dilakukan setelah model dari penelitian ini memenuhi syarat-syarat yaitu lolos dari asumsi klasik. Syarat-syarat yang harus dipenuhi adalah data tersebut harus terdistribusikan secara normal, tidak mengandung multikoloniaritas, dan heterokedastisitas. Untuk itu sebelum melakukan pengujian regresi linier berganda perlu dilakukan lebih dahulu pengujian asumsi klasik, yang terdiri dari berikut ini.

\section{Uji Normalitas}


Pengujian normalitas memiliki tujuan untuk menguji apakah dalam model regresi, variabel penganggu atau residual memiliki distribusi normal. penelitian ini menggunakan analisis grafik. Data dapat dikatakan normal jika data atau titik-titk terbesar di sekitar garis diagonal dan penyebarannya mengikuti garis diagonal. Pada prinsipnya normalitas dapat dideteksi dengan melihat penyebaran data (titik) pada sumbu diagonal dari grafik atau dengan melihat histrogram dari residualnya. (Ghozali, 2013).

2. Uji Multikolinearitas

Uji Multikolonieritas bertujuan untuk menguji apakah model regresi ditemukan adanya korelasi antar variabel bebas (Ghozali, 2013). Cara untuk mengetahui apakah terjadi multikolonieritas atau tidak yaitu dengan melihat nilai Tolerance dan Variance Inflation Factor (VIF).

3. Uji Heteroskedastisitas

Jika variance dari residual satu pengamatan ke pengamatan yang lain tetap, maka disebut Homokedastisitas dan jika berbeda disebut Heteroskedastisitas. Uji ini dapat dilakukan dengan melihat gambar plot antara nilai prediksi variabel independen (ZPRED) dengan residualnya (SRESID). Apabila dalam grafik tersebut tidak terdapat pola tertentu yang teratur dan data tersebar secara acak di atas dan di bawah angka 0 pada sumbu Y, maka diidentifikasikan tidak terdapat heteroskedastisitas (Ghozali,2013).

\section{Model Regresi}

Alat analisis yang digunakan adalah analisis regresi berganda linier, data diolah dengan bantuan software SPSS versi 20. Pengujian hipotesis dilakukan dengan menggunakan model analisis regresi variabel independen terhadap variabel dependen (sekaran, 2011). dengan persamaan regresi adalah:

dimana :

$$
\mathbf{Y}=\alpha+b_{1} \mathrm{X}_{1}+b_{2} \mathrm{X}_{2}+b_{3} \mathrm{X} 3+b_{4} \mathrm{X}_{4}+e
$$

$\mathrm{Y}=$ Belanja Modal untuk pelayanan Publik

$\mathrm{X}_{1}=$ Pertumbuhan PAD

$\mathrm{X}_{2}=$ Desentralisasi Fiskal

$\mathrm{X}_{3}=$ Efektivitas Keuangan Daerah

$\mathrm{X}_{4}=$ Efisiensi Keuangan Daerah

\section{Pengujian Hipotesis}

Perhitungan statistik disebut signifikan secara statistik apabila nilai uji statistiknya berada dalam daerah kritis (daerah dimana $\mathrm{H}_{0}$ ditolak). Sebaliknya disebut tidak signifikan bila nilai uji statistiknya berada dalam daerah dimana $\mathrm{H}_{0}$ diterima (Ghozali, 2013).

1. Uji Signifikansi Bersama-sama (Uji F-Statistik)

Uji F pada dasarnya menunjukkan apakah semua variable independen atau bebas yang dimasukkan dalam model mempunyai pengaruh secara bersama-sama terhadap variabel dependen (Ghozali, 2013). Cara untuk mengetahuinya yaitu dengan membandingkan nilai $\mathrm{F}$ hitung dengan nilai $\mathrm{F}$ tabel. Apabila nilai $\mathrm{F}$ hitung lebih besar daripada nilai $\mathrm{F}$ tabel, maka hipotesis alternatif diterima artinya semua variabel independen secara bersama-sama dan signifikan mempengaruhi variabel dependen.

1. Uji Signifikansi Parameter Individual (Uji t-Statistik)

Apabila nilai $t$ hitung lebih besar dibandingkan dengan nilai t tabel maka berarti $t$ hitung tersebut signifikan artinya hipotesis alternatif diterima yaitu variabel independen secara individual mempengaruhi variabel dependen. Selain itu, bisa juga dilakukan dengan melihat $p$-value dari masing-masing variabel. Hipotesis diterima apabila $p$-value $<5 \%$ (Ghozali, 2013). dasar pengambilan keputusan untuk uji t (parsial) dalam analisis regresi. Berdasarkan nilai t hitung dan $\mathrm{t}_{\text {tabel, }}$ adalah:

a. Jika $t_{\text {hitung }}>t_{\text {tabel, }}$ maka hipotesis diterima

b. Jika $t_{\text {hitung }}<t_{\text {tabel, }}$ maka hipotesis ditolak 
Berdasarkan nilai signifikansi hasil output SPSS adalah:

a. Jika signifikansi $>\alpha 0,05$, maka hipotesis ditolak.

b. Jika signifikansi $<\alpha 0,05$, maka hipotesis diterima. 


\section{HASIL PENELITIAN DAN PEMBAHASAN}

\subsection{Hasil Penelitian Hasil Analisis Regresi

$$
\mathrm{Y}=0.207+0.047 \mathrm{X}_{1}-0.290 \mathrm{X}_{2}+0.006 \mathrm{X}_{3}+0.006 \mathrm{X}_{4}
$$

Dari persamaan regresi linier berganda di atas, dapat menginformasikan hal-hal sebagai berikut.

1. Nilai konstan sebesar 0.207 artinya jika variabel Pertubuhan PAD $\left(\mathrm{X}_{1}\right)$, Desentralisasi Fiskal $\left(\mathrm{X}_{2}\right)$, Efektivitas Keuangan Daerah $\left(\mathrm{X}_{3}\right)$ dan Efisiensi Keuangan Daerah $\left(\mathrm{X}_{4}\right)$ dianggap konstan, maka Belanja publik akan sebesar 0.207.

2. Koefisien $X_{1}$ Pertumbuhan PAD (Growth) sebesar 0.047 yang berarti setiap kenaikan satu persen Variabel growth $\left(\mathrm{X}_{2}\right)$ maka akan menaikkan belanja modal untuk pelayanan publik sebesar 0,047 dengan asumsi faktor-faktor lain dianggap tetap (citeris paribus).

3. Koefisien $X_{2}$ Desentralisasi Fiskal sebesar -0,290 yang berarti setiap kenaikan variabel desentralisasi fiskal $\left(\mathrm{X}_{3}\right)$ sebesar satu persen maka akan menurunkan belanja modal untuk pelayanan publik sebesar 0,290 dengan asumsi faktor-faktor lain dianggap tetap (citeris paribus).

4. Koefisien $\mathrm{X}_{3}$ Efektivitas Keuangan Daerah sebesar 0.006 yang berarti setiap kenaikan variabel efektivitas keuangan daerah $\left(\mathrm{X}_{3}\right)$ sebesar satu persen maka akan meningkatkan belanja modal untuk pelayanan publik sebesar 0.006 dengan asumsi faktor-faktor lain dianggap tetap (citeris paribus).

5. Koefisien $\mathrm{X}_{4}$ Efisiensi Keuangan Daerah sebesar 0.006 yang berarti setiap kenaikan variabel efisiensi keuangan daerah $\left(\mathrm{X}_{5}\right)$ sebesar satu persen maka akan meningkatkan belanja modal untuk pelayanan publik sebesar 0.006 dengan asumsi faktor-faktor lain dianggap tetap (citeris paribus).

\section{Pengujian Hipotesis Secara Simultan (Uji F)}

Berdasarkan hasil uji $\mathrm{F}$, diperoleh $\mathrm{F}$ hitung sebesar 4,665 dengan tingkat signifikansi atau probabilitas sebesar $0,003<\alpha=0,05$, maka $\mathrm{H}_{5}$ diterima artinya variabel pertumbuhan PAD (growth), desentralisasi fiskal, efektivitas keuangan daerah dan efisiensi keuangan daerah berpengaruh signifikan terhadap belanja modal untuk pelayanan publik.

Berdasarkan hasil uji $\mathrm{F}$ diketahui bahwa kinerja keuangan pemerintah daerah variabel pertumbuhan PAD (growth) $\left(\mathrm{X}_{1}\right)$, desentralisasi fiskal $\left(\mathrm{X}_{2}\right)$, efektivitas keuangan daerah $\left(\mathrm{X}_{3}\right)$, dan efisiensi keuangan daerah $\left(\mathrm{X}_{4}\right)$ secara bersama- sama (simultan) berpengaruh signifikan terhadap belanja modal untuk pelayanan publik, dengan nilai $\mathrm{F}$ hitung sebesar 4.665 dengan nilai signfikansi 0,003. Dari nilai adjusted $R$ square, didapatkan bahwa $19.9 \%$ dependen variabel dapat dijelaskan oleh variasi dari 4 variabel independen.

\section{Pengujian Hipotesis Secara Parsial (Uji t)}

Uji t adalah untuk menguji pengaruh variabel bebas secara parsial atau sendiri-sendiri, untuk mengetahui kemampuan dari masing-masing variabel dalam mempengaruhi variabel dependent, dengan menganggap variabel lain konstan/tetap.

Nilai $t_{\text {tabel }}$ dengan jumlah sampel $(n)=60$,jumlah variabel $(k)=5$, taraf signifikan $\alpha=$ $0,05 / 2=0,025$ (uji 2 sisi); degree of freedom $(\mathrm{df})=\mathrm{n}-\mathrm{k}=60-6=54$ sehingga diperoleh nilai $\mathrm{t}_{\text {tabel }}$ sebesar $\pm 2,004$.

Berdasarkan Tabel 5.5 diperoleh:

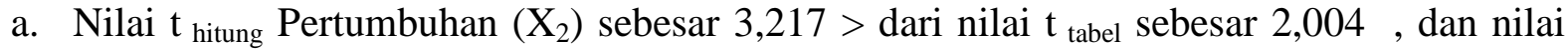
signifikansi $\mathrm{P}=0,002<\alpha=0.05$, maka $\mathrm{H}_{01}$ ditolak, yang berarti $\mathrm{H}_{\mathrm{a} 1}$ diterima artinya variable Pertumbuhan PAD berpengaruh positif dan signifikan terhadap belanja publik.

b. Nilai $t_{\text {hitung }}$ Desentralisasi fiscal $\left(\mathrm{X}_{2}\right)$ sebesar $-1,305<$ dari nilai $t_{\text {tabel }}$ sebesar 2,004 dan nilai signifikansi $\mathrm{P}=0,197>\alpha=0.05$, maka $\mathrm{H}_{\mathrm{o} 2}$ diterima dan $\mathrm{H}_{\mathrm{a} 2}$ ditolak, artinya variabel desentralisasi fiskal $\left(\mathrm{X}_{2}\right)$ berpengaruh negatif dan tidak signifikan terhadap belanja publik. 
c. Nilai $\mathrm{t}$ hitung efektivitas $\left(\mathrm{X}_{3}\right)$ sebesar $0,162<$ dari nilai $\mathrm{t}$ tabel sebesar 2,004 dan nilai signifikansi $\mathrm{P}=0,872>\alpha=0.05$, maka $\mathrm{H}_{03}$ diterima dan $\mathrm{H}_{\mathrm{a} 3}$ ditolak, artinya variabel efektivitas keuangan $\left(\mathrm{X}_{3}\right)$ berpengaruh positif dan tidak signifikan terhadap belanja public.

d. Nilai $t_{\text {hitung }}$ efisiensi keuangan $\left(\mathrm{X}_{4}\right)$ sebesar 0,243 > dari nilai $\mathrm{t}_{\text {tabel }}$ sebesar 2,014 dan nilai signifikansi $\mathrm{P}=0,809<\alpha=0.05$, maka $\mathrm{H}_{04}$ diterima dan $\mathrm{H}_{\mathrm{a} 4}$ ditolak, artinya variable efisiensi keuangan $\left(\mathrm{X}_{5}\right)$ berpengaruh positif dan tidak signifikan terhadap belanja publik.

\subsection{Pembahasan}

\section{Pengaruh Pertumbuhan (growth) PAD Terhadap Belanja Modal Untuk Pelayanan Publik}

Hasil uji t terhadap variabel Pertumbuhan (growth) PAD berpengaruh positif dan signifikan terhadap belanja modal untuk publik. Semakin besar PAD suatu daerah akan semakin meningkat anggaran belanja modal untuk pelayanan public yang di provinsi Sulawesi utara. Menurut Halim (2007:241) rasio pertumbuhan mengukur seberapa besar kemampuan pemerintah dalam mempertahankan dan meningkatkan keberhasilan yang telah dicapainya dari periode ke periode berikutnya.

Walaupun trend pendapatan asli daerah naik turun namun pemerintah daerah yang ada diPsulawesi utara telah mengalokasikan belanja modal lebih besar namun masih adanya pertumbuhan yang negatif, maka dalam kondisi ini juga mengharuskan pemerintah daerah untuk berusaha mengali potensi pajak daerah masing - masing dan bekerja keras demi tercapainya realisasi pendapatan melebihi target yang ada pada APBD.

Penelitian ini tidak sejalan dengan penelitian Yovita (2011) PAD tidak berpengaruh terhadap alokasi belanja modal namun penelitian ini konsisten dengan penelitian verawaty, dkk.(2015), sulistyowati (2011)

\section{Pengaruh Desentralisasi Fiskal Terhadap Belanja Modal Untuk Pelayanan Publik}

Hasil uji t menunjukkan bahwa variabel desentralisasi fiskal berpengaruh negatif dan tidak signifikan terhadap belanja modal untuk pelayanan publik di provinsi Sulawesi utara. Apabila rasio desentralisasi fiscal menurun akan meningkatkan pembiayaan belanja modal untuk publik dari sumber penerimaan yang lain hal ini berarti bahwa kemampuan pemerintah daerah di provinsi Sulawesi utara dalam rangka meningkatkan PAD guna membiayai pembangunan masih sangat kurang, yang menunjukkan masih kurangnya kesadaran masyarakat untuk membayar pajak dan restibusi daerah. Pemerintah daerah perlu melakukan sosialisasi tentang pajak daerah yang telah ditetapkan serta upaya untuk menggali potensi pajak daerah.

Secara konseptual, desentralisasi fiskal mensyaratkan bahwa setiap kewenangan yang diberikan kepada daerah harus disertai dengan pembiayaan yang besarnya sesuai dengan besarnya beban kewenangan tersebut. Konsep ini dikenal dengan money follow function, bukan lagi function follow money. Artinya, pemerintah pusat berkewajiban menjamin sumber keuangan terkait dengan pendelegasian wewenang dari pusat ke daerah.

Mengukur kinerja/kemampuan keuangan pemerintah daerah dapat dilakukan dengan menggunakan indikator Derajat Desentralisasi Fiskal (Musgrave \& Musgrave, 1980). Desentralisasi Fiskal adalah ukuran untuk menunjukkan tingkat kewenangan dan tanggung jawab yang diberikan pemerintah pusat kepada pemerintah daerah untuk melaksanakan pembanguna akan tetapi. DAU pada kenyataannya merupakan sumber pendanaan terbesar dan utama bagi pemerintah daerah yang diperoleh dari transfer pemerintah pusat kepada daerah.

Pada prinsipnya kebijakan desentralisasi fiskal mengharapkan ketergantungan daerah terhadap pusat berkurang, sehingga mampu mencapai kemandirian daerah sebagaimana tercapainya tujuan otonomi itu sendiri. Menurut Halim (2011), ketergantungan kepada bantuan pusat harus seminimal mungkin, sehingga Pendapatan Asli Daerah (PAD) harus menjadi sumber keuangan terbesar yang didukung oleh kebijakan perimbangan keuangan pusat dan daerah. Sejalan dengan Waluyo, (2007) yang mengatakan bahwa idealnya semua pengeluaran daerah 
dapat dipenuhi dengan menggunakan Pendapatan Asli Daerah (PAD) sehingga daerah dapat benar- benar otonom, tidak lagi tergantung ke pemerintah pusat.

Dengan demikian Pendapatan Asli Daerah (PAD) memiliki peran yang sangat sentral dalam membiayai pelaksanaan pemerintahan daerah. Dalam UU Nomor 33 Tahun 2004 tentang Perimbangan Keuangan Antara Pusat Daerah disebutkan bahwa PAD bertujuan memberikan kewenangan kepada pemerintah Daerah untuk mendanai pelaksanaan otonomi daerah sesuai dengan potensi daerah sebagai perwujudan desentralisasi.

Santosa dan Rahayu (2005) menyebutkan bahwa PAD sebagai salah satu peneriamaan daerah mencerminkan tingkat kemandirian daerah. Semakin besar PAD maka menunjukan bahwa daerah mampu melaksanakan desentralisasi fiskal dan ketergantungan terhadap Pemerintah Pusat berkurang. Namun demikian kebijakan- kebijakan desentralisasi fiskal yang ada tidak sertamerta dapat membangun kemandirian daerah dengan cepat.

Landiyanto (2005) dalam penelitiannya tentang Kinerja Keuangan Dan Strategi Pembangunan Kota Di Era Otonomi Daerah Di Kota Surabaya menemukan bahwa ketergantungan daerah terhadap pusat masih tinggi karena belum optimalnya penerimaan dari PAD dan belum optimalnya pendapatan/laba BUMD. Sampai saat ini potensi pendapatan asli daerah masih menitikberatkan pada perolehan pajak dan retibusi daerah. Butuh waktu yang lama untuk membangun kemandirian daerah dalam membiayai anggaran pengeluaran belanja daerah minimal belanja pegawainya.

Hasil penelitian ini sejalan dengan hasil penelitian Fitri (2013) bahwa kecilnya PAD yang digunakan dalam membiayai belanja modal untuk pelayanan publik dan besarnya ketergantungan pemintah daerah terhadap dana transfer untuk membiayai pembangunan. Penelitian yang dilakukan oleh Febrian (2011) membuktikan bahwa pemerintah daerah masih banyak merespon pengeluaran daerahnya dari transfer pemerintah pusat yang bersifat tidak bersyarat daripada pendapatan asli daerahnya.

\section{Pengaruh Efektivitas Keuangan Daerah Terhadap Belanja Modal Untuk Pelayanan Publik}

Hasil uji t menunjukan efektivitas pengelolaan keuangan daerah berpengaruh positif dan tidak signifikan terhadap belanja modal untuk pelayanan publik. Hal ini menandakan bahwa jumlah realisasi PAD lebih kecil daripada target/alokasi yang dianggarkan. mengindikasikan bila suatu keuangan daerah dikatakan tidak efektif maka timbul asumsi daerah tersebut merealisasi jumlah anggaran belanja modal rendah khususnya untuk kepentingan publik. Alasan lain rasio ini diukur dari jumlah realisasi PAD dibandingkan dengan anggarannya maka dilihat dari data yang ada masih banyaknya daerah di provinsi Sulawesi Utara yang jumlah PAD-nya masih sangat kecil daripada yang dianggarkan, sehingga untuk membiayai belanja public sangat kurang atau tidak mencukupi dibiayai dari PAD.

Rasio efektifitas menggambarkan kemampuan pemerintah daerah dalam merealisasikan PAD yang direncanakan dibandingkan dengan target yang ditetapkan berdasarkan potensi riil daerah. Semakin besar realisasi penerimaan PAD dibanding target penerimaan PAD, maka dapat dikatakan semakin efektif, begitu pula sebaliknya.

Hasil penelitian ini tidak berhasil membuktikan penelitian sebelumnya yang dilakukan oleh Azkiya (2011) yang menyatakan efektivitas berpengaruh positif signifikan terhadap belanja modal. Penelitian ini berhasil membuktikan penelitian Vella, dkk (2014) yang menyatakan rasio efektivitas keuangan daerah tidak memiliki pengaruh yang signifikan terhadap alokasi belanja modal di kabupaten/kota Provinsi Riau. Kondisi ini terjadi kemungkinan disebabkan oleh tuntutan dan kebutuhan masyarakat setempat cenderung diabaikan sehingga pengalokasian belanja modal tidak terealisasi dengan efektif dan dapat menghambat pembangunan untuk meningkatkan pelayanan publik. Sementara dana pada anggaran daerah yang pada dasarnya merupakan dana publik sebagian besar dibelanjakan untuk belanja pegawai, sehingga pemerintah perlu melakukan reservasi dan identifikasi ulang terhadap jumlah kebutuhan alokasi dana dari seluruh kegiatan secara lebih akurat dan detail sesuai dengan kebutuhan yang sebenarnya, baik 
yang bersifat rutin maupun pembangunan untuk meningkatkan pelayanan publik (Dwirandra 2015).

\section{Pengaruh Efisiensi Keuangan Daerah Terhadap Belanja Modal Untuk Pelayanan Publik}

Hasil uji t menunjukan efisiensi pengelolaan keuangan daerah berpengaruh positif dan tidak signifikan terhadap Belanja modal untuk publik. Semakin tinggi atau semakin kecil rasio efisiensi pengelolaan keuangan maka semakin tinggi pula belanja modal untuk publik. Alasan efisiensi keuangan daerah tidak berpengaruh terhadap pengalokasian belanja modal karena keuangan daerah pemerintah daerah provinsi Sulawesi utara tidak efisien masih terjadi tumpang tindih pendanaan dan tidak sesuai dengan implementasi anggarannya (Fitri, 2013).

Menurut Fitri (2013), Rasio efisiensi adalah rasio yang menggambarkan perbandingan antara output dan input atau realisasi pengeluaran dengan realisasi penerimaan daerah. Semakin kecil rasio ini, maka semakin efisien, begitu pula sebaliknya. Dalam hal ini dengan mengasumsikan bahwa pengeluaran yang dibelanjakan sesuai dengan peruntukkannya dan memenuhi dari apa yang direncanakan, (Ardhini, 2011). Suatu kegiatan dikatakan telah dikerjakan secara efisien jika pelaksanaan pekerjaan tersebut telah mencapai hasil (output) dengan biaya (input) yang terendah atau dengan biaya minimal diperoleh hasil yang diinginkan yang menekankan pada prinsip money follows function. Mardiasmo, (2002: 169).

Penelitian ini tidak konsisten dengan hasil penelitian Ardhini (2011), Hidayat (2013), Sularso dan Restianto (2011), serta Kusumawati (2011) yang menyatakan bahwa rasio efisiensi keuangan daerah berpengaruh terhadap pengalokasian belanja modal. Tetapi konsisten dengan penelitian Fitri (2011) verawaty dkk.(2015) dan Handayani (2012).

\subsection{Kesimpulan}

\section{KESIMPULAN DAN SARAN}

Berdasarkan pengujian statistik dengan menggunakan regresi linier berganda, maka kesimpulan dari penelitian ini adalah sebagai berikut.

1. Pertumbuhan PAD berpengaruh positif dan signifikan terhadap belanja modal untuk pelayanan publik,.

2. Desentralisasi fiskal berpengaruh negatif dan tidak signifikan terhadap belanja modal untuk pelayanan publik.

3. Efektivitas keuangan daerah berpengaruh posotif dan tidak signifikan terhadap belanja modal untuk pelayanan publik.

4. Efesiensi keuangan daerah berpengaruh positif dan tidak signifikan terhadap belanja modal untuk pelayanan publik.

\subsection{Saran}

Berdasarkan penelitian yang dilakukan maka disarankan hal-hal sebagai berikut.

1. Untuk Pemerintah Daerah di Sulawesi Utara sebaiknya lebih memperhatikan bagaimana meningkatkan kinerja instansi sehingga diharapkan akan meningkatkan Pendapatan Asli (PAD) daerah berupa, pajak daerah, retribusi daerah, alokasi anggaran ke belanja modal untuk pelayanan publik juga dapat meningkat.

2. Untuk penelitian selanjutnya, sebaiknya menggunakan rentang waktu penelitian yang lebih panjang agar memperoleh hasil yang lebih relevan.

3. Penambahan variabel baru sebagai variabel independen maupun variabel dependen sangat penting untuk melengkapi hasil penelitian terdahulu.

\subsection{Keterbatasan}

Penelitian ini mempunyai beberapa keterbatasan sebagaai berikut. 
1. Periode penelitian hanya 6 tahun (untuk masing-masing variabel) yaitu dari tahun 20102015 sehingga hasil yang didapatkan belum dapat diintepretasikan secara maksimal.

2. Variabel independen yang digunakan hanya terbatas pada komponen yang tercantum dalam laporan realisasi anggaran, tanpa menambahkan variabel lain di luar laporan realisasi anggaran.

\section{DAFTAR PUSTAKA}

Agustina, 2013. Jurnal Analisis Kinerja Pengelolaan Keuangan Daerah dan Tingkat Kemandirian Daerah. Studi Kasus Kota Malang (Tahun Anggaran 2007-2011). Jurnal Ilmu Ekonomi Fakultas Ekonomi dan Bisnis Universitas Brawijaya Malang.

Ahmad Kudhori. 2015. Pengaruh Kinerja Keuangan Pemerintah Daerah terhadap Alokasi Belanja Modal untuk Publik. Ekonomaks Volume 4 No.1 Maret 2015.

Ardhini dan Handayani, Sri. 2011. Pengaruh Rasio Keuangan Daerah Terhadap Belanja Modal Untuk Pelayanan Publik Dalam Perspektif Teori Keagenan (Studi Pada Kabupaten Dan Kota Di Jawa Tengah). Universitas Diponegoro. Semarang.

Assyurriani, 2015. Pengaruh Rasio Kemandirian Daerah, Rasio Efektivitas, Rasio Efisiensi, Rasio Aktivitas, dan Rasio Pertumbuhan Terhadap Belanja Modal Pada Pemerintah Kabupaten dan Pemerintah Kota di Kepulauan Riau Tahun 2010-2013. Jurnal Ekonomi Tanjungpinang.

Badan Litbang Depdagri Republik Indonesia dan FISIPOL-UGM, 1991, Pengukuran Kemampuan Keuangan Daerah Tingkai II Dalam Rangka Otonomi Daerah Yang Nyata dan Bertanggung Jawab, Jakarta.

Badan Pusat Statistik Provinsi Sulawesi Utara. 2016. Sulawesi Utara Dalam Angka 2016.

Bahrudin, R. 2012. Pengaruh Desentralisasi Fiskal terhadap Belanja Modal, Pertumbuhan Ekonomi, dan Kesejahteraan Masyarakat Kabupaten/Kota di Provinsi Jawa Tengah. Disertasi Universitas Airlangga,

Batinggi. 2005. Materi Pokok Pelayanan Umum. Jakarta: Universitas Terbuka.

Bregman. M. and Lane. J.E. 1990. Public Policy in a Principal Agent Framework. Journal of Theoretical Politics 2(3). 339-352.

Darwanto dan Yulia Yustika Sari. 2007. Pengaruh Pertumbuhan Ekonomi, Pendapatan Asli Daerah, Dana Alokasi Umum Terhadap Pengalokasian Belanja Modal. Simposium Nasional Akuntansi X Makassar 26-28 Juli 2007.

Dwirandra. 2008. "Efektivitas dan Kemandirian Keuangan Daerah Otonom Kabupaten/Kota di Propinsi Bali Tahun 2002 - 2006”, Jurnal Ilmiah. Jurusan Akuntansi, Fakultas Ekonomi Udayana, Denpasar.

Endah Kusumawati, Vegasari. 2011. Faktor-Faktor yang Menentukan Pendapatan Asli Daerah dan Belanja Modal di Indonesia Survei pada Pemerintahan Daerah di Indonesia Bagian Barat dan Tengah.

Febrian. 2011. Analisis Pengaruh Dana Alokasi Umum (DAU) dan Pendapatan Asli Daerah (PAD) terhadap belanja daerah di Kabupaten Boyolali

Fitri, Vella Kurniasih. 2013. Pengaruh rasio keuangan daerah, Pendapatan Asli Daerah (PAD), dan Dana Alokasi Umum (DAU) terhadap alokasi belanja modal pada kabupaten/kota di Provinsi Riau Tahun 2009-2012. Universitas Riau. Riau

Gamkhar Shama, and Oates Wallace E. 1996. Asymmetries in the Response to Increases and Decreases in Intergovernmental Grants: Some Empirical Findings, National Tax Journal vol 49 (December 1996) no.4 pp.501-12

Gavin Lawrie, Dirk Kalff and Henrik Andersen .2005. Balanced Scorecard and Results-Based Management: Convergent Performance Management Systems, Presented at 3rd Annual Conference on Performance Measurement and Management Control, The European 
Institute for Advanced Studies in Management (EIASM), September 2005, Nice, France.

Ghozali, Imam. 2013. Aplikasi Analisis Multivariate dengan Program IBM SPSS 21. Semarang Badan Penerbit Universitas Diponegoro.

Griner, E.H \& Gordon, L.A. 1995. "Internal cash flow, insider ownership and capital expenditures; a test of the pecking order and managerial hypotheses". Journal of Business Finance \& Accounting, 22(2), 179-199.

Gujarati, Damodar N. 2013.Dasar-Dasar Ekonometrika.Edisi 5 Buku 2. Jakarta:Salemba Empat Halim, Abdul. 2004. Manajemen Keuangan Daerah.Yogyakarta: (UPP) AMP YKPN Halim, Abdul.2011.Pengelolaan Keuangan Daerah. Edisi Ketiga. UPP AMP YKPN

Halim dan Kusufi. 2012. Akuntansi Sektor Publik: “Akuntansi Keuangan Daerah”. Jakarta: Salemba Empat.

Hidayat, F. M. dan Ghozali, M. 2013. Analisis Pengaruh Kinerja Keuangan Daerah Terhadap Alokasi Belanja Modal (Studi pada Kabupaten dan Kota di Jawa Timur). Jurnal Ilmiah, Malang :Universitas Brawiajaya.

Jensen, M. and Meckling, W., 1976. "Theory of the Firm: Managerial Behavior, Agency Cost and Ownership Structure." Journal of Financial Economics 3(305-360).

Kartika. dan Kusuma 2011. Analisis rasio kemandirian, rasio Efektivitas, dan rasio Efisiensi Pada Laporan reslissasi Anggaran.

Khusaini, Muhamad, 2006. Ekonomi Publik : Desentralisasi Fiskal dan Pembangunan Daerah, BPFE Unbraw, Malang.

Kuncoro, Mudrajat, 2004, Otonomi dan Pembangunan Daerah, Erlangga, Jakarta.

Kusumawati, Vegasari Endah. 2010. Faktor-Faktor Yang Menentukan Pendapatan Asli Daerah Dan Belanja Modal Di Indonesia. Universitas Muhamadiyah Yogyakarta.

Lago-Peñas, Santiago 2005 : The Effects Of Grants Cuts On Public Deficit - Does Incumbent's Ideology Matter?, 45th Congress of the European Regional Science Associati on: "Land Use and Water Management in a Sustainable Network Society", 23-27 August 2005, Amsterdam, The Netherlands .

Lane, Jan-Erik. 2003. Management and public organization: The principal-agent framework. University of Geneva and National University of Singapore. Working paper.

Lin Justin Yifu dan Zhiqiang Liu. 2006. Fiscal Decntralization and Economic Growth in China. Economic Development and Cultural Change. Chicago. Vol 49. USA.

Mardiasmo. 2009. Akuntansi Sektor Publik. Penerbit Andi. Yogyakarta.

Martini dan Dwirandra. 2015. Pengaruh Kinerja Keuangan Daerah pada Alokasi Belanja Modal di Provinsi Bali. E-Jurnal Akuntansi Universitas Udayana 10.2(2015):426-443

Moe, T.M. 1984. The New Economics of Orgaanization. American Journal of Political Science 28(5):739-777.

Ni Putu Dwi Eka Rini Sugiarthi, Ni Luh Supadmi. 2014. Pengaruh PAD, DAU, dan SiLPA pada Belanja Modal dengan pertumbuhan ekonomi sebagai Pemoderasi. e-Jurnal Akuntansi Universitas Udayana 7.2 (2014): 477-495.

Nguyen, L.P dan Anwar, S. 2011. Fiscal Decentralization and Economic Growth in Vietnam. Journal of Asia Pacific Economy. Volume. 16, No. 1 Februari: 13-14.

Nopiani, Ni Made, Wayan Cipta, dan Fridayana Yudiaatmaja. 2016. Pengaruh Pendapatan Asli Daerah, Dana Alokasi Umum, Dan Belanja Modal Terhadap Pertumbuhan Ekonomi. eJournal Bisma Universitas Pendidikan Ganesha Jurusan Manajemen, 4:1-12.

Oesi Agustina. A 2013. Analisis Kinerja Pengelolaan Keuangan Daerah dan Tingkat Kemandirian Daerah Di Era Otonomi Daerah: Studi Kasus Kota Malang (Tahun Anggaran 2007-2011) eJurnal FEB UB

Prakosa, Kesit Bambang. 2004. Pengaruh Dana Alokasi Umum (DAU) dan Pendapatan Asli Daerah (PAD) terhadap Prediksi Belanja Daerah (Studi Empirik di wilayah Provinsi Jawa Tengah dan DIY).JAAI Vol. 8 No. 2.

Pusdiklatwas BPKP. 2007. Administrasi Keuangan II. Jakarta. Edisi 5. Jakarta 
Saad, Ilyas., 2003. "Implementasi Otonomi Daerah sudah mengarah pada Distorsi dan High Cost Economy". Semeru Working Paper.

Sagita, Desandry, Dwi. 2010. Peran Kualitas Pelayanan Pelanggan Tentang Prosedur Pemasangan Jaringan Baru dan Perubahan Daya Listrik PT PLN (Pesero) Area Pelayanan Jaringan Surabaya Selatan. Surabaya: Perpustakaan STIKOM Surabaya.

Santoso, Singgih. 2012. Analisis SPSS pada Statistik Parametrik. Jakarta: PT. Elex Media Komputindo.

Setiawan, Hadi. 2013. Kinerja Keuangan Daerah pada Era Otonomi , Risiko Fiskal Daerah Menjaga Kesehatan Fiskal dan Kesinambungan Pembangunan. Era Adicitra Intermedia.

Stine William F. 1994, Is Local Government Revenue Response To Federal Aid Symmetrical? Evidence From Pennsylvania County Governments In An Era Of Retrenchment, National Tax Journal Vol. 47, no. 4, (December, 1994), pp. 799-816

Sularso, Havid., Restianto, Yanuar E. 2011. Pengaruh Kinerja Keuangan Terhadap Alokasi belanja Modal dan Pertumbuhan Ekonomi Kabupaten/Kota di Jawa Tengah. Media Riset Akuntansi, Vol 1, No.2, Agustus 2011.

Kurniasih, Vella Fitri. 2014. "Pengaruh Rasio Keuangan Daerah, Pendapatan Asli Daerah (PAD) Dan Dana Alokasi Umum (DAU) Terhadap Alokasi Belanja Modal Pada Kabupaten/Kota Di Provinsi Riau Tahun 2009-2012”. Jurnal Universitas Riau. Riau.

Verawaty, Citra Indah Meirina. 2015. Analisis Belanja Modal pada Anggaran Pemerintah Daerah dalam Hubungannya dengan Belanja Pemeliharaan (Studi Kasus pada Pemerintah Kabupaten/ Kota di Provinsi Sumatera Selatan).

Yovita, Farah Marta. 2011. "Pengaruh Pertumbuhan Ekonomi, Pendapatan Asli Daerah dan Dana Alokasi Umum Terhadap Pengalokasian Anggaran Belanja Modal (Studi Empiris pada Pemerintah Provinsi Se Indonesia Periode 2008 -2010)”. Diponegoro Jurnal Of Accounting. Semarang: UNDIP.

Yustikasari, Yulia, dan Darwanto. 2007. Pengaruh Pertumbuhan Ekonomi, Dana Alokasi Umum (DAU) dan Pendapatan Asli Daerah (PAD) terhadap Pengalokasian Anggaran Belanja Modal. Jurnal Kritis: Univeritas Gadjah Mada Yogyakarta.

Zimmerman, Jerold L. 1977, "The Municipal Accountong Maze: Analysis of Political Incentives".Studies on Measurement and Evaluation of the Economic Efficiency of Public and Private Nonprofit Institution pp 107-144.

Republik Indonesia. (2014). Undang-Undang Republik Indonesia No. 23 Tahun 2014 tentang Pemerintahan Daerah. Jakarta: Indonesia.

(2004). Undang-Undang Republik Indonesia No. 33 Tahun 2004 tentang Perimbangan Keuangan Antara Pusat dan Daerah. Jakarta: Indonesia.

. (2009). Undang-Undang Republik Indonesia No. 28 Tahun 2009 tentang Pajak Daerah dan Retribusi Daerah. Jakarta: Indonesia.

. (2011). Peraturan Menteri Dalam Negeri No. 21 tahun 2011 tentang Pengelolaan Keuangan Daerah. Jakarta: Indonesia.

(2010). Peraturan Pemerintah Republik Indonesia No. 71 tahun 2010 tentang Standar Akuntansi Pemerintahan. Jakarta: Indonesia.

(2006). Peraturan Menteri Dalam Negeri No. 13 tahun 2006 tentang Pedoman

Pengelolaan Keuangan Daerah. Jakarta: Indonesia.

. (2010). Peraturan Pemerintah Republik Indonesia No. 71 tahun 2010 tentang Standar Akuntansi Pemerintahan. Jakarta: Indonesia.

.(2005). Peraturan Pemerintah Republik Indonesia No 56 Tahun 2005 tentang Sistem Informasi Keuangan Daerah. Jakarta: Indonesia.

. (2005). Peraturan Pemerintah RI No 56 Tahun 2005 tentang Sistem Informasi Keuangan Daerah. Jakarta: Indonesia.

. (1996). Keputusan Menteri Dalam Negeri mendagri No. 690.900.327 Tahun 1996

tentang Pedoman Penilaian Kinerja Keuangan. Jakarta: Indonesia. 
(2005). Peraturan Menteri Dalam Negeri No. 58 tahun 2005 tentang Pengelolaan Keuangan Daerah. Jakarta: Indonesia.

(1993)Keputusan Menpan no. 81 tahun 1993 tentang Penyelengaraan Pelayanan Publik, Jakarta: Indonesia

(2003).Keputusan Menpan No: 63/KEP/M.PAN/7/2003 tentang Pedoman Umum Penyelenggaraan Pelayanan Publik. Jakarta: Indonesia. 